\title{
Complicații materne şi fetale apărute în trombofilia de cauză ereditară
}

\author{
Janina-Georgiana Nacea1,3, Nicolae Cernea ${ }^{2,3}$, Viorela Enăchescu ${ }^{1,3}$, \\ Loredana Anghel ${ }^{2}$, Constantin Kamal', Ion Cristian Efrem ${ }^{1,3}$, \\ Ana-Maria Pătraşcu²,3, Ionela Rotaru ${ }^{1,3}$ \\ ${ }^{1}$ Universitatea de Medicină şi Farmacie din Craiova, România \\ ${ }^{2}$ Spitalul Clinic Judeţean de Urgenţă din Craiova, România \\ ${ }^{3}$ Spitalul Clinic Municipal Filantropia din Craiova, România
}

\begin{abstract}
REZUMAT
Obiectiv. Identificarea modificărilor calitative şi cantitative ale mutaţiile factorilor de coagulare implicate în complicaţii materne şi fetale, determinarea nivelului de corelaţie dintre acestea şi gradul de implicare al trombofiliei ereditare în rândul femeilor însărcinate.

Material şi metodă. Articolul se bazează pe 92 de publicaţii din 1995 până în 2017, incluzând 49.127 de paciente cu trombofilie, dintre care 1.272 au fost martori, având drept criterii de includere în studiu prezenţa preeclampsiei, retardul de creştere intrauterină sau pierderea timpurie sau tardivă a sarcinii.

Rezultate. 31 studii bazate pe preeclampsie demonstrează implicarea mutaţiei genei G1691A factor $V$ Leiden, a mutaţiei genei G20210A a protrombinei şi a mutaţiei genei C677T şi A1298C MTHFR ca factori principali în dezvoltarea acestei complicaţii. 10 studii se concentrează asupra gradului de restricţie de creştere intrauterine, iar mutaţia genei G20210A a factorului V Leiden, mutaţia genei G20210A a protrombinei, mutaţia genei C677T şi A1298C MTHFR, deficitul de proteina C şi proteină S fiind principalii factori implicaţi. Alte 32 de studii citează implicarea mutaţiei factorului $V$ Leiden, a mutaţiei protrombinei şi a mutaţiei MTHFR în dezvoltarea pierderilor de sarcină precoce sau tardive.

Concluzii. Pe baza a 92 de publicaţii riguros selectate, am putut demonstra relaţia dintre trombofilia cu risc mediu/crescut şi rezultatul sarcinii, în special din cauza prezenţei mutaţiei genei factor $V$ Leiden, a mutaţiei genei protrombinei, dar şi a statusului homozigot al mutaţiei genei MTHFR.
\end{abstract}

Cuvinte cheie: hipercoagulabilitate, homozigot, factori de coagulare, preeclampsie, restricţie de creştere intrauterină, avort spontan recurent

\section{INTRODUCERE}

Este bine cunoscut faptul că trombofilia moştenită sau dobândită reprezintă condiții protrombotice, care pot duce la complicații cum ar fi tromboembolismul venos (VTE), mai frecvent decât la persoanele sănătoase. Prevalența acestei afecțiuni este în creştere, iar mai mult de $50 \%$ dintre pacienții cu tromboză venoasă profundă de cauze necunoscute prezintă mutații ale factorilor de coagulare (1). Pacienții pot fi mai mult sau mai puțin simptomatici în funcție de starea de dublu heterozigot sau homozigot.

Tromboza şi fiziopatologia sa se bazează pe triada Virchow: deteriorarea pereților vaselor de sân- ge, turbulența fluxului sanguin sau staza şi hipercoagulabilitatea sângelui (2).

Mai mult, încercăm să subliniem importanța acestei boli la femeile gravide prin complicațiile care pot apărea.

\section{Trombofilia ereditară}

Mai întâi, trombofilia de cauză moştenită, poate duce la complicații grave, în special asociate cu factorii de risc. Acestea sunt polimorfisme ereditare care afectează în principal genele care codifică factorii implicați în coagulare, reprezentând un factor important de risc pentru tromboză. Starea homozigotă, mai puțin frecventă decât cea heterozi- 
gotă, face ca riscul de tromboză să crească semnificativ. De asemenea, prezența mai multor mutații ale factorilor de coagulare la acelaşi individ (status dublu heterozigot) predispune la consecințe notabile (3).

În funcție de frecvență, pot să apară:

- Mutaţia G1691A a genei factorului V Leiden,

- Mutația G20210A a genei protrombinei,

- Deficitul de antitrombină III,

- Mutaţia C677T şi A1298C a genei metilenetetrahidrofolat reductaza (MTHFR),

- Hiperhomocisteinemia,

- Deficit de proteine C şi S,

- Creşterea inhibitorului activatorului de plasminogen (PAI)

Trombofiliile ereditare cu o frecvență mare în populație şi un risc ridicat sunt: factorul $\mathrm{V}$ Leiden (hetero/homozigot), mutatia genei G20210A a protrombinei (hetero/homozigotă), status dublu heterozigot V Leiden şi mutația protrombinei. Trombofilia cu frecvență mică, dar cu risc foarte crescut de tromboză, este deficiența antitrombinei III, risc crescut de tromboză deficitul proteinelor C şi S (fals pozitive în timpul sarcinii). Sa demonstrat în mai multe rânduri că, separat, fiecare dintre acestea nu poate produce schimbări semnificative la femeile gravide, ci prin asociere acestea pot creşte dramatic aparitia trombozei venoase (4). Asocierile cu factori de risc dobândiți cum ar fi cancerele, contraceptivele orale, sarcini sau imobilizarea postpartum prelungită agravează starea de hipercoagulabilitate.

\section{Trombofilia şi sarcina}

Sarcina este, de asemenea, o condiție de hipercoagulabilitate, dar fiziologică, cu risc crescut de dezvoltare a trombozei venoase. La femeile gravide, exceptând TEV, această stare protrombotică, trombofilia, poate duce la complicații cum ar fi preeclampsia, pierderea precoce sau tardivă a sarcinii, restricția creşterii intrauterine (RCI) şi chiar dezlipire de placentă. Dar este foarte important să știm că nu toate femeile gravide cu trombofilie pot dezvolta aceste complicații şi, tocmai din acest motiv, screening-ul pentru această boală nu este efectuat în mod obişnuit. Acesta trebuie efectuat numai dacă există factori de risc pentru dezvoltarea trombozei (5).

Ghidurile de Obstetrică şi Ginecologie includ trombofilia la gravide în mai multe categorii, în funcție de factorul de risc tromboembolic şi de frecvență.

Prezența deficienței antitrombinei III în stare heterozigotă determină un risc crescut de tromboză dar o frecvență redusă (Tabelul 1). Prezența factorului $\mathrm{V}$ Leiden/rezistența la proteina $\mathrm{C}$ activată şi mutația G20210A a genei protrombinei în stare homozigotă sunt singurele cu risc crescut de tromboză, dar cu frecvență nu foarte crescută. De asemenea, în această categorie cu risc crescut, intră şi asocierea dintre mutația G20210A a genei protrombinei şi mutația factorului V Leiden (dublu heterozigot). Următoarele, în funcție de risc (risc moderat), sunt prezența factorului V Leiden/rezistență la proteina C activată şi mutaţia G20210A a genei protrombinei, de această dată heterozigotă. Iar cu frecvență redusă şi risc moderat sunt deficitul proteinei $\mathrm{C}$ şi proteinei $\mathrm{S}(6)$.

\section{OBIECTIVE}

Analiza rolului mutaţiilor factorilor de coagulare în aparițiile tuturor complicațiilor materne şi fetale şi revizuirea celor mai recente actualizări privind implicațiile acestora, identificarea modificărilor calitative şi cantitative care implică factori de coagulare implicați în complicațiile materne şi fetale şi determinarea nivelului de corelație între acestea pentru a evidenția o viziune mai bună a prognosticului acestor pacienți.

\section{MATERIAL ŞI METODĂ}

Revizuirea extensivă a articolelor a fost realizată de doi evaluatori independenţi. Au fost incluse în studiu 92 de publicații. Pentru a restrânge zona de cercetare, s-au folosit cuvinte cheie relevante precum trombofilie, tromboembolism venos, sarcină, preeclampsie, restricție de creştere intrauterină

TABELUL 1. Riscul tromboembolic şi frecvența factorilor de coagulare

\begin{tabular}{|l|c|c|c|c|}
\hline & Risc cresct & Risc moderat & Risc scăzut & Frecvență \\
\hline Factor V Leiden & Status Homozigot & Status Heterozigot & & Crescută \\
\hline Antitrombina III & Status Hetero/homozigot & & & Scăzută \\
\hline mutația protrombinei & Status Homozigot & Status Heterozigot & & Crescută \\
\hline Proteine C/S & & Status Hetero/homozigot & & Scăzută \\
\hline MTHFR & & & Status Hetero/homozigot & Crescută \\
\hline PAI & & & Status Hetero/homozigot & Crescută \\
\hline
\end{tabular}


(RCI), pierderi de sarcină, factori de coagulare şi corelarea acestora cu complicaţiile materne şi fetale. Au fost utilizate studii randomizate, review-uri, studii prospective şi retrospective.

Criteriile de includere au fost bazate pe populația feminină diagnosticată cu trombofilie în prezența sau absența unui factor de risc personal sau familial pentru tromboembolism venos (TEV), dar şi a prezenței complicațiilor materne şi fetale, cum ar fi RCI, preeclampsie, pierderi de sarcină precoce sau tardive.

Analiza statistică: extragerea datelor a fost efectuată sistematic prin selectarea studiilor sugestive publicate utilizând baze de date electronice cum ar fi PubMed (Medline) între 1995 și 2017, publicații Cochrane, Google Scholar, Embase şi interfaţa OVID, publicatiii de specialitate, conferințe, sesiuni de studiu, selectând toate publicațiile care au îndeplinit criteriile de includere.

Calitatea datelor a fost evaluată utilizând Scala Newcastel-Ottawa (NOS) şi doi evaluatori independenți au analizat calitatea datelor $\mathrm{cu}$ ajutorul formularelor standardizate pentru utilizarea datelor.

Toate datele colectate au fost salvate într-o arhivă electronică pentru a fi revizuite ori de câte ori este nevoie şi de mai mult de un evaluator. Analiza statistică a fost efectuată în principal utilizând programe informatice şi formule de calcul pentru raportul de probabilitate (OR) şi intervalele de încredere (IC), testul lui Fisher, testele t, testul Chi-pătrat (x2).

\section{REZULTATE}

\section{Trombofilia ereditară şi preeclampsia}

Au fost selectate 27 de articole care demonstrează asocierea dintre trombofilia ereditară şi preeclampsie pentru a evidenția implicarea mutațiilor factorilor de coagulare în dezvoltarea acestei complicații. Din publicațiile selectate, un risc crescut de preeclampsie şi preeclampsie severă a fost raportat la femeile gravide cu mutație heterozigotă a factorului V Leiden, mutație heterozigotă a protrombinei şi mutație homozigotă a MTHFR (7). Un total de 2.264 de femei însărcinate au fost incluse în toate cele 27 de studii, fără factori de risc.

O meta-analiză ce include 31 de studii, efectuată de Lin J şi colab., evidențiază la o parte importantă a pacienţilor cu preeclampsia, modificări ale factorilor de coagulare, respectiv mutația factor V Leiden cu OR (odds ratio) 5.3 (IC 95\%, 1,8-15,6), mutația homozigotă MTHFR cu OR 3,9 (IC 95\%,
0,7-20,6) sau mutația protrombinei cu OR 4,7 (IC $95 \% ; 1,5-15,0)(8)$.

Chiar dacă în publicațiile selectate pentru studiul nostru au existat diferențe minore în rata de probabilitate (OR), concluziile rămân aceleaşi, în fața unei gravide cu preeclampsie sau preeclampsie severă şi trombofilie de cauză moştenită, principalii factori de risc pentru apariția acestor complicații rămân prezența mutației heterozigote a FVL, a mutaţiei heterozigotă G20210A a protrombinei şi a mutației homozigotă a MTHFR. O proporție mai mică de studii, în special din cauza frecvenței scăzute, a demonstrat, de asemenea, implicarea deficitului de antitrombină III şi de proteine C şi S în această complicație de temut cu OR 9,7 (95\% CI $1,2-7,8)$ şi o valoare a lui $\mathrm{p}<0,01(9-10)$.

\section{Trombofilia ereditară şi pierderea de sarcină}

Fiind cea mai de temut complicaţie ce poate apărea la femeile gravide cu status protrombotic ereditar, trombofilia a devenit din ce în ce mai intens studiată pentru a demonstra o corelație între aceasta şi complicațiile care pot apărea în decursul sarcinii (11).

Am selectat 32 de articole dintre cele mai semnificative concentrate pe pierderile de sarcină precoce sau tardive (12). În peste $80 \%$ dintre acestea, implicarea mutaţiei factor V Leiden (FVL) şi a mutației G20210A a protrombinei în pierderea tardivă de sarcină (al doilea şi al treilea trimestru) a fost deosebit de puternică (10-20). Pe de altă parte, mutaţia homozigotă MTHFR, deficitul proteinelor C şi $\mathrm{S}$ au fost implicate într-o măsură mai mică în apariţia acestei complicații, fiind astfel un număr mic de articole care au putut demonstra o legătură între prezența acestor mutaţii şi pierderile precoce de sarcină (trimestrul 1 de gestație) (13).

Am întâmpinat dificultăţi în evaluarea implicației antitrombinei III şi avorturile spontane din cauza frecvenței reduse a acestei anomalii. Chiar dacă în majoritatea articolelor această mutație a fost găsită în mai puțin de $10 \%$ dintre cazuri, toate acestea au specificat asocierea dintre deficitul de antitrombină III şi pierderile precoce de sarcină (14).

Dintr-un total de 4.520 de gravide cu pierderi de sarcină recurente în trimestrul I (TI) sau trimestrul II-III (TII-III), sa putut observa o corelație strânsă între mutaţia factor $\mathrm{V}$ Leiden, mutația protrombinei şi pierderea tardivă a sarcinii cu OR 3,2 (95\% IC 1,0-10,9) pentru FVL, şi OR 3,3 (95\% IC 1,0-10,9) pentru protrombină, cu o valoare $p=0,001$, dar şi asocierea într-o măsură mai mică a mutației MTHFR, deficitul de antitrombină III, deficitul 
proteinelor $\mathrm{C}$ şi $\mathrm{S}$ şi pierderea precoce a sarcinii cu risc semnificativ mai mare OR 5,2 (95\% IC, 1,5$18,1)$ / OR 2,3 (95\% IC, 0,6-8,3) respectiv OR 3,3 $(95 \%$ IC, 1,0-11,3). Acest fapt a făcut posibilă demonstrarea relației strânse între avorturile spontane şi trombofilie în comparație cu lotul martor, OR 3,6 comparativ cu OR 1,20 în grupul martor (12-15).

Turki şi col. încearcă să coreleze avorturile spontane recurente cu polimorfismele trombofilice. Studiul demonstrează o asociere semnificativă între mutaţia FVL, mutația G20210A a protrombinei, mutația C677T a MTHFR şi riscul ridicat de pierderi tardive din 171 de cazuri cu pierderi de sarcină recurente. OR estimat pentru pacienții cu pierdere de sarcină şi FVL a fost de 2,3, pentru protrombină 3,9 şi 1,9 pentru mutația MTHFR. Cel mai mare OR pentru pierderile de sarcină a fost în cazul mutațiilor combinate 14,3, comparativ cu riscul ce apare în absența asocierii (14).

Isaoglu U. şi colab. au constatat o relație între pierderea recurentă de sarcină şi trombofilia moştenită. Rezultatele lor arată că dintre 60 de subiecți cu avorturi spontane recurente, 13 au fost purtători ai mutaţiei factor V Leiden şi 6 ai mutației G20210A a protrombinei (13).

De asemenea, Parand A. şi colab. au încercat să demonstreze acelaşi lucru, implicarea deficitului de proteină S în pierderile de sarcină recurente la 90 de pacienți cu rezultate semnificative, cu $\mathrm{p}=0,03$ (14).

Studiul nostru demonstrează în continuare, pe baza numărului mare de rezultate, că trombofilia se asociază cu complicații de temut la femeile gravide (12-17). În ceea ce priveşte avorturile spontane, sa demonstrat în mai multe rânduri că factorul V Leiden şi mutaţia protrombinei sunt implicate în mod special în pierderile tardive de sarcină OR 2,4 (95\% IC; $0,78-7,61) p=0,001$ (16-18). Chiar dacă am întâmpinat dificultăți în evidențierea unei corelații între deficitul de antitrombină III şi pierderile de sarcină, pe baza a $10 \%$ dintre toate articolele revizuite, am putea afirma că această anomalie, dar şi deficiența proteinelor $\mathrm{C}$ şi $\mathrm{S}$ au fost şi sunt implicate în avorturile spontane precoce OR 2,9 (IC 95\%, $1,8-4,8) p=0,02$. Cu precizarea că acestea au fost determinate în afara sarcinii, fiind bine cunoscut faptul că aceste proteine scad fiziologic în timpul sarcinii (17).

\section{Trombofilia ereditară şi RCI}

A fost demonstrat în multe publicații că populația feminină care suferă de trombofilie este susceptibilă pentru dezvoltarea restricției de creştere intrauterină şi nu numai.
Investigată excesiv, putem spune că trombofilia a devenit din ce în ce mai frecventă în rândul femeilor însărcinate. Dar este extrem de important să se cunoască factorii de risc care prezintă probleme în evoluția sarcinii (6). Există un număr mare de femei cu mutații ale factorilor de coagulare, dar fără factori individuali de risc, fără antecedente de pierdere de sarcină în al doilea sau al treilea trimestru, fără un istoric familial semnificativ, femei care de cele mai multe ori vor avea o evoluție normală a sarcinii fără complicații. Atunci când este prezentă mutația homozigotă a factorului V Leiden sau mutația G20210A a protrombinei, putem încadra trombofilia în risc crescut de apariție a complicațiilor (3-5).

Din toate publicaţiile revizuite, am selectat 10 cele mai potrivite, implicând 470 gravide cu trombofilie, dintre care $343 \mathrm{cu}$ restricție de creştere intrauterină (18).

Coriu şi colab., într-un studiu efectuat pe 151 de pacienți cu restricție de creştere intrauterină, au semnalat în special prezenta mutației G20210A a protrombinei şi, într-un procent mai mic, a putut fi găsită mutaţia G1691A şi C677T a MTHFR. Riscul RCI la pacienții cu factor V Leiden este de 2,66 ori mai mare decât grupul martor OR 2,66 (95\% IC $0,96-7,37 ; p=0,059)(18)$.

Livrinova şi colab. au încercat să sublinieze asocierea dintre preeclampsie, RCI, dezlipirea de placentă şi prezența mutaţiei factorului V Leiden, mutației G20210A a protrombinei, a mutaţiei genei MTHFR într-un studiu bazat pe 109 subiecți, incluzând 40 de paciente cu preeclampsie, 17 cu dezlipire de placentă, 22 cu restricție de creştere şi 30 de pacienți martori. Au fost observate rezultate semnificative - riscul relativ (RR) la pacienții cu FVL şi RCI a fost de 2,58, iar la pacienții cu mutația homozigotă a MTHFR şi RCI a fost de 2,03, cu semnificație statistică importantă $\mathrm{p}<0,05$ (19).

Un alt studiu, de data aceasta o meta-analiză bazată pe 42 de publicații, implică mutația factorului V Leiden în dezvoltarea RCI, această asociere fiind semnificativă cu OR de 1,32 (95\% CL 0,15-11,30) şi $\mathrm{p}<0,05$ (21).

Kupferminc şi colab. subliniază o prevalență semnificativă a RCI în rândul gravidelor cu mutație homozigotă a factorului V Leiden, mutaţie homozigotă G20210A a protrombinei şi deficitul de proteină S (10).

Revizuirea noastră selectivă pentru restricția de creştere intrauterină (RCI) a furnizat dovezi semnificative asupra implicațiilor factorilor de coagulare în această complicație. Astfel, în mai mult de 70\% dintre publicațiile revizuite, autorii au întâlnit peste 
75\% dintre femeile gravide cu restricție de creştere intrauterină ca purtătoare ale mutației factorului V Leiden (fie homozigotă, fie heterozigotă), fie a mutației G20210A a protrombinei (homozigotă sau heterozigotă), singura care prezintă un risc semnificativ pentru dezvoltarea RCI (OR 4,2; CI 95\%; 1,6$10,9, \mathrm{p}<0,001)(17-23)$. În restul cazurilor, autorii nu au reuşit să demonstreze o corelaţie între RCI şi mutațiile factorilor de coagulare comparativ cu martorii. Există, de asemenea, o serie de publicații care au încercat să evidențieze asocierea restricției de creştere intrauterină cu mutația A1298C sau/şi C677T MTHFR, dar fără un risc semnificativ de a dezvolta aceasta complicaţie $(p>0,05)(15-20)$.

Putem afirma, pe baza celor mai importante publicații selectate pentru studiul nostru, că mutația FVL, mutația G20210A protrombinei, mutația homozigotă A1298C sau C677T MTHFR prezintă cel mai mare risc de a dezvolta complicaţii materne şi fetale bazate pe OR calculat pentru fiecare studiu (Tabelul 2).

\section{Trombofilia ereditară şi dezlipirea de placentă}

O altă complicație teribilă ce ar putea fi asociată cu trombofilia ereditară este susținută de o multitudine de studii publicate în ultimii 10 ani. De această dată, au fost selectate 24 de publicații bazate pe asocierea dintre trombofilia ereditară şi dezlipirea de placentă, incluzând aproximativ 21.000 de femei selectate pentru a stabili o corelație strânsă între această complicație şi trombofilia de cauză ereditară. Am obținut rezultate pozitive până în prezent, astfel încât, în majoritatea studiilor, sa putut observa o corelație strânsă între dezlipirea de placentă şi mutația heterozigotă a factorului V Leiden cu un OR de aproximativ 9 (19-21).

Un studiu al lui Said şi colab. cuprinde 117 cazuri cu complicații dezvoltate pe parcursul sarcinii: preeclampsie (45), RCI (44), dezlipire de placentă (14), moarte fetală intrauterină (10) şi 115 paciente martor, încercând să obțină o corelație între cele mai frecvente complicații apărute pe parcursul sarcinii şi trombofilia ereditară. Rezultatele lor au fost interpretate cu prudență, deoarece au existat doar 16 cazuri ce au dezvoltat dezlipire de placentă în prezența mutației heterozigote a FVL cu OR 3,68 (95\% CI 1,20-10,61) (20).

În meta-analiza realizată de Rodger şi colab., bazată pe 10 publicații, se încearcă demonstrarea unei corelaţii între rezultatele sarcinii şi prezenţa mutaţiei factorului $\mathrm{V}$ Leiden sau a mutaţiei G20210A a protrombinei, rezultat ce nu a putut fi susținut în această meta-analiză (21).

Din totalul de 20.175 de femei cu dezlipire placentară, $14,1 \%$ au fost purtători ai mutației heterozigote a FVL - o lucrare realizată de Prochazka şi colab. pentru a stabili o corelație între dezlipirea de placentă şi femeile cu trombofilie ereditară. Aşadar, a putut fi susţinută corelaţia dintre dezlipirea placentară şi mutaţia heterozigotă a factorul V Leiden cu un OR $(1,24-2,92)(20-23)$.

Într-un alt studiu, o meta-analiză realizată de Robertson şi colab., a fost evidențiată o asociere semnificativă între mutația heterozigotă a FVL şi dezlipirea placentară cu OR 4,7, dar şi între mutația heterozigotă a protrombinei cu un OR 4,9 (1.122.30) (22).

TABELUL 2. Odds ratio întâlnită în cele mai semnificative publicații

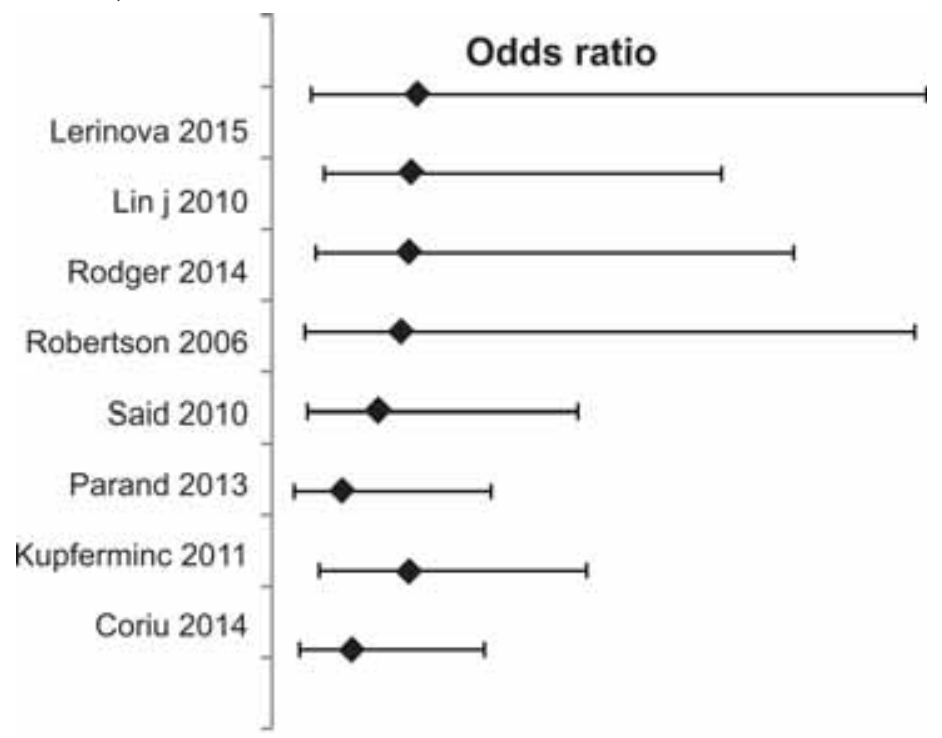




\section{DISCUŢII}

Studiul efectuat reprezintă o revizuire a 92 de articole pe o perioadă cuprinsă între 1995 şi 2017 care demonstrează relația dintre trombofilia cu risc crescut sau scăzut şi complicațiile apărute în timpul sarcinii (preeclampsie, RCI, pierderea recurentă a sarcinii, dezlipire de placentă). Acest lucru este evidențiat de toate informațiile obținute din revizuirea celor 92 de articole bazate exclusiv pe relația dintre rezultatul sarcinii şi trombofilia de cauză ereditară folosind OR, intervalul de încredere (IC) cu o valoare $\mathrm{p}<0,05$.

Din punctul de vedere al modificărilor factorilor de coagulare, am putut observa implicarea mutaţiei heterozigote/homozigote a factorului $\mathrm{V}$ Leiden într-o proporție mare în majoritatea complicațiilor dezvoltate în timpul sarcinii, în special în preeclampsie, în RCI, în pierderea recurentă a sarcinii şi în dezlipire de placentă, mutație cu risc crescut şi frecventă mare în dezvoltarea TEV. De asemenea, a fost găsită mutația homozigotă a MTHFR la pacienții cu RCI, preeclampsie şi pierderea precoce a sarcinii.

Un rezultat similar a fost observat şi în cazul mutației G20210A a protrombinei, atât hetero cât şi homozigot, la majoritatea pacienților care au dezvoltat complicații în timpul evoluției sarcinii, astfel că toate publicațiile revizuire descriu mutația protrombinei ca fiind implicată în preeclampsia şi RCI.

În studiul nostru am evidențiat date statistice substanțiale privind corelația dintre mutaţia factorului V Leiden, mutația genei protrombinei şi avorturile spontane, în special cele tardive, fără a reuşi să demonstrăm o corelație strânsă între deficitul de antitrombină III, proteină S şi proteină C în primul rând din cauza frecvenței lor scăzute. În cazul ultimelor două, situația este mult mai delicată din cauza rezultatelor fals pozitive apărute în timpul sarcinii, ştiind foarte bine că acestea scad fiziologic cu sarcina, motiv pentru care ar trebui să fie efectuate înainte de concepere. Din cauza lipsei datelor care să ateste că profilul trombofilic a fost efectuat în absența sarcinii, este dificil de spus că deficitul de proteină $\mathrm{C}$ sau de proteină $\mathrm{S}$ este implicat în repercusiunile materne şi fetale. Chiar dacă deficitul de antitrombină III este considerat ca având cel mai mare risc de dezvoltare a trombozei, din cauza incidenței scăzute, a fost dificil să apreciem implicațiile sale în rândul femeilor însărcinate în cele 92 de publicații incluse.

Dintre toate publicaţiile implicate în studiu, $76 \%$ dintre acestea au putut demonstra asocierea mutațiilor factorilor de coagulare cu complicațiile apărute, dar am considerat important să specificăm că aproximativ $20 \%$ dintre acestea nu au putut dovedi această asociere în comparație cu martorii. Aşadar, s-a putut demonstra în mai multe rânduri că trombofiliile cu risc crescut, mutația hetero/homozigot a factorului V Leiden, mutaţia genei protrombinei, dar şi asocierea acestora (status dublu heterozigot) pot produce complicații notabile în rândul femeilor însărcinate. De asemenea, pe lângă aceşti factori de coagulare, fără alți factori de risc personal sau familial, evoluția sarcinii este similară cu cea a martorilor.

Concentrându-ne pe obiectivul principal al studiului, am reuşit să stabilim trombofiliile cu risc crescut de tromboză şi de apariție a complicațiilor pe parcursul sarcinii, pe baza a 92 articole care au inclus $>49.000$ de femei gravide cu trombofilie, în principal pentru a reduce numărul de cazuri inutil testate pentru profilul trombofilic (şi implicit a costurilor) şi pentru a preveni administrarea terapiei anticoagulante atunci când nu este aplicabilă. Acest lucru este realizabil şi prin trierea mai riguroasă a pacienților care nu prezintă factori de risc personali sau familiali cu indicație pentru efectuarea profilului trombofilic.

Studiul nostru evidenţiază descoperiri semnificative, şi anume că: mutația genei protrombinei, mutaţiafactorului V-Leiden şi, într-o mai mică măsură, mutaţia genei MTHFR reprezintă singurele mutaţii cu risc crescut în apariția preeclampsiei, RCI, a avorturilor spontane tardive şi a dezlipirii de placentă, exceptând deficitul antitrombinei III, unde am întâmpinat dificultăți în demonstrarea relației cu repercusiunile materne şi fetale din cauza incidenței scăzute.

\section{CONCLUZII}

Dezbaterile recente s-au axat pe corelarea dintre mutaţiile factorilor de coagulare şi complicațiile dezvoltate în timpul sarcinii.

În concluzie, mutațiile factorilor de coagulare interferează cu apariția complicațiilor în timpul sarcinii. Astfel, pe baza riscului de probabilitate calculat, factorul V Leiden reprezintă principala mutație implicată în preeclampsie, în întârzierea creşterii intrauterine şi, în special, în pierderea tardivă a sarcinilor cu un OR de 4,7 (IC 95\%, 1,5-15,0), OR 5,5 (1,37-22,4), respectiv OR 3,48 (CI 95\%, 1,587,69). Mutația genei MTHFR a fost implicată în mod special în preeclampsie, lucru evident într-un număr mult mai mic de studii cu OR 3,9 (95\% CL; $0,7-20,6)$. 
Pe baza a $10 \%$ dintre toate articolele revizuite, putem afirma că deficitul de antitrombină III, deficitul de proteine $\mathrm{C}$ şi $\mathrm{S}$ au fost şi sunt implicate în pierderi precoce de sarcină cu OR 2,9 (CI 95\%; $1,8-4,8)$ cu un $p=0,02$. Un OR mai mare a fost evident în cazul defectelor combinate ale factorilor de coagulare (dublu heterozigot) de 14,3 în comparație cu pacienții purtători ai unei singure mutații.

Având în vedere dovezile incontestabile, este nevoie de o mai bună abordare a acestei afecțiuni, în primul rând de informare în masă a pacienților, întrucât utilizarea testelor profilului trombofilic este încă inadecvată în rândul femeilor însărcinate, şi, în al doilea rând, dezvoltarea unor programe de screening țintite.

Subliniem încă o dată faptul că mutaţia genei heterolhomozigote a factorului V-Leiden, mutația hetero/homozigotă a protrombinei sau asocierea acestora sunt cele care pot evolua cu complicații importante în decursul sarcinii. De asemenea, în prezența altor modificări ale factorilor de coagulare însă în absența unui factor de risc (antecedente de avorturi spontane tardive, moarte fetală intrauterină, antecedente personale sau familiale de trombofilie, antecedente personale sau familiale de tromboză venoasă profundă la vârste sub 40 de ani), evoluția sarcinii este similară cu cea în absența trombofiliei.

Este nevoie de o mai bună înțelegere a acestui fenomen, fiind insuficient cercetat, deoarece există încă multiple lacune în sistem.

Conflict of interest: none declared Financial support: none declared 